Elżbieta BUCHCIC

AŚ Kielce

\title{
Wykorzystanie środowiska lokalnego dla kształtowania postaw na rzecz zrównoważonego rozwoju
}

\author{
„... Nauka potrzebuje nowej śmiałości \\ w myśleniu wolnym i twórczym, \\ wykazującym werspektywie wiarę, \\ w zrozumienie pytań $i$ wyzwań, \\ jakie niesie życie, aby w końcu \\ wydobywać ostateczne prawdy o czlowieku \\ i jego miejscu na Ziemi ....." \\ Jan Paweł II \\ (L'Osservatore Romano 16.12.2001)
}

Ukierunkowanie oświaty na edukację dla zrównoważonego rozwoju jest obecnie priorytetowym zadaniem każdej szkoły. Aktywność proekologiczna dzieci i młodzieży na rzecz ochrony środowiska jest zróżnicowana i często niewystarczająca na różnych etapach nauczania. Przejawia się ona najczęściej w deklaracjach, a w mniejszym stopniu w działaniu. Wychowanie ucznia zaangażowanego w lokalne problemy środowiskowe nie może dokonać się bez nasilonego zaangażowania, dobrze przygotowanego merytorycznie i metodycznie nauczyciela.

Prowadząc zajęcia edukacyjne w zakresie tematyki dotyczącej zrównoważonego rozwoju należy stosować różnorodne strategie, metody i formy nauczania, które umożliwiają uczniom współuczestnictwo w poznawaniu zagrożeń środowiska poprzez aktywne zaangażowanie $w$ badania, monitoring i podejmowane przedsięwzięcia na rzecz rozwoju miejsca zamieszkania. Dzieci i młodzież powinna prowadzić podstawowe badania i analizy, oceniać na ich podstawie procesy zachodzące w środowisku oraz zrozumieć ich przyczyny oraz skutki.

Szkoła jest środowiskiem wychowawczym, które na przełomie dzieciństwa i młodości odgrywa ogromną rolę w życiu młodego człowieka. Dlatego dla zrozumienia zjawisk zachodzących $w$ środowisku niezbędne jest posiadanie odpowiedniej wiedzy, która powinna być przekazywana na porównywalnym poziomie, 
odpowiadającym współczesnym wymogom. Sposób i zakres przekazywania tych wiadomości, umiejętności oraz postaw musi być procesem kształcenia ustawicznego ponieważ osiągnięcia nauki i techniki ulegają ciągłemu rozwojowi.

Placówki oświatowe odgrywają wiodącą rolę w edukacji, ale nie mogą być jedynym źródłem wiedzy. Czynić to należy współdziałając z innymi instytucjami i organizacjami zarówno $z$ edukacji formalnej i nieformalnej, realizując ważne postanowienia międzynarodowe dotyczące założeń ochrony środowiska i ekorozwoju. Upowszechnienie proekologicznego sposobu myślenia winno być zagadnieniem pierwszoplanowym w każdej dziedzinie działalności człowieka, a zwłaszcza w racjonalnej ochronie środowiska na wszystkich szczeblach kształcenia.

Elementarna wiedza z zakresu zrównoważonego rozwoju, jest obecnie niezbędną częścią w wykształceniu ludzi pracujących w każdym zawodzie, ponieważ realizacja założeń ekorozwoju wymaga wysokiej społecznej świadomości.

Nauczyciel poszukujący, zaangażowany i twórczy powinien motywować swoich wychowanków do podejmowania działania, gdyż pozwoli to im wykazać się własną inicjatywą, a to z kolei przyczyni się do rozwoju ich osobowości. Uczeń podejmujący działanie po pewnym czasie przyjmie postawę wykonywania danego rodzaju działania. Stanie się zwolennikiem tego działania, będzie zachęcał innych często będzie pełnił odpowiednią funkcję. Najwyższą, osiągalną kategorią celów motywacyjnych jest system działań, gdzie uczeń nie zawodzi nawet w trudnych sytuacjach, jego działania są skuteczne, a zdobyte wiadomości i umiejętności potrafi zastosować $w$ każdym przypadku. ${ }^{1}$

Dlatego nauczyciel we współczesnej szkole winien stale poszukiwać coraz to nowych, skuteczniejszych metod aktywizowania uczniów w procesie dydaktycznym, wyzwalając tym samym u nich pozytywną motywację uczenia się, przynoszącą satysfakcję. Bogactwo treści programowych, jakie zawierają zajęcia w najbliższym środowisku, wyznacza procesowi dydaktyczno - wychowawczemu duże zadanie, w związku z realizacją szeroko pojętych celów dotyczących nie tylko wiadomości i umiejętności, ale również i postaw. Młody człowiek poznaje na zajęciach, pod kierunkiem nauczycieli i pracowników instytucji zajmujących się edukacją środowiskową, otaczającą go przyrodę i poszczególne jej elementy, ustosunkowuje się do nich, kształtując własne określone postawy.

M. JAGODZIŃSKA, Zalożenia programowe i charakterystyka procesu edukacyjnego $w$ zakresie kształcenia przyrodniczego. [w:] Ksztakcenie przyrodnicze $w$ szkole podstawowej-teoria i praktyka. Red. D. Cichy Ośrodek Doskonalenia Nauczycieli, Płock 2005, s. 22. 


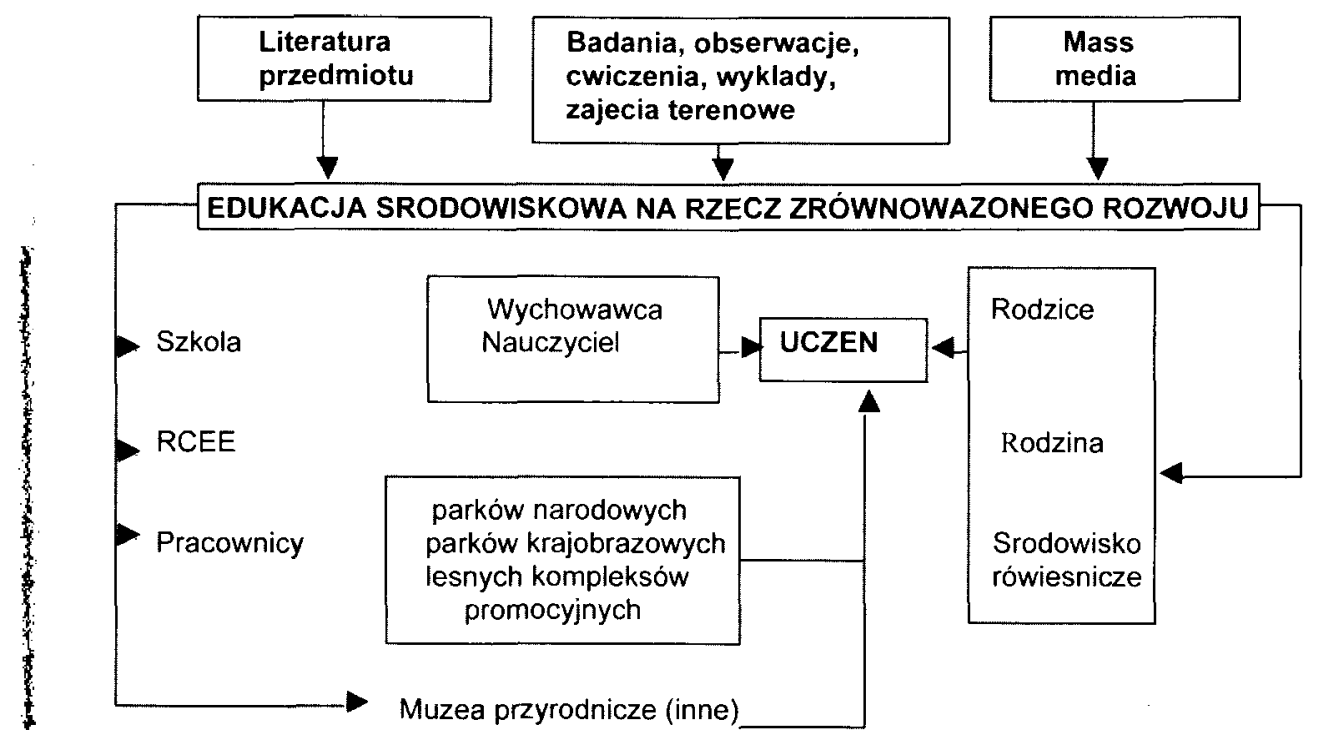

Ryc. 1. Edukacja środowiskowa na rzecz zrównoważonego rozwoju ${ }^{2}$

Zajęcia, które odbywają się w środowisku naturalnym spełniają wielu funkcji nie tylko dydaktycznych, ale również wychowawczych, zdobyte na lekcjach wiadomości oraz nabyte umiejętności można sprawdzić w praktycznym działaniu. Pozyskana wiedza może być poddana kontroli, ocenie i ewaluacji w warunkach naturalnych. Warto również zaakcentować ich ogromne znaczenie w kształtowaniu prawidłowych postaw dzieci i młodzieży wobec środowiska.

Cichy $(1984)^{3}$ za postawy proekologiczne przyjmuje:

- poczucie moralnej odpowiedzialności za jakość otaczającego środowiska przyrodniczego i społecznego,

- gotowość uczestniczenia w działaniach zmierzających do ochrony i ulepszania otaczającego środowiska,

- afirmację uznanych przez innych racji i wartości dotyczących działań człowieka w środowisku.

Autorka uważa, że postawy to odpowiedzialny stosunek do środowiska, tzn. przestrzeganie pewnych zasad moralnych wynikających nie tylko z reakcji lękowych przed sankcjami, lecz również $z$ uznania pewnego systemu wartości

2 E. Buchcic, Zielone szkoły-działalność i możliwości podwyższania skuteczności edukacyjnej. Ośrodek Doskonalenia Nauczycieli, Płock 2005, s. 105.

3 D. CICHY, Przygotowanie mlodzieży do ochrony i ksztaltowania środowiska. LOP. Warszawa 1984, s. 36. 
i przyjęcia go jako kryterium własnego postępowania (internalizacja). Należy stwierdzić, że rola szkoły w kształtowaniu pozytywnych postaw dzieci i młodzieży względem przyrody i problemów jej ochrony jest niebagatelna.

Wiedza obiektywna o świecie jest sumą informacji, której można się nauczyć w procesie kształcenia. Jednak nie można tylko teoretycznie nauczyć się miłości do przyrody i troski o nią. Aksjomaty kultury, zasady moralności, nawyk działania proekologicznego można zdobyć jedynie w procesie wychowania. Świadomość ekologiczna nie jest bowiem sumą uzyskanej informacji, lecz efektem własnych przemyśleń i doświadczeń (Nowak, Żeber-Dzikowska). ${ }^{4}$ Kształtowanie w procesie wychowania orientacji, uczuć, pasji wywiera wpływ na późniejsze postępowanie człowieka w środowisku przyrodniczym i wobec tego środowiska. Zdaniem autorek wychowanie przyśpiesza proces przekształcenia nabytej wiedzy ekologicznej w normy codziennego życia. Potrzeba ochrony środowiska staje się nawykiem i jest uwzględniona na każdym stanowisku pracy, a także w decyzjach mikro-i makro- gospodarczych.

Według Dołęgi edukacyjna problematyka ekofilozofii dotyczy przede wszystkim podstaw filozoficznych wychowania proekologicznego, a ściślej mówiąc wychowania sozologicznego w rodzinie, w szkole, w masmediach, w organizacjach społecznych, religiach oraz w ogólnej edukacji narodowej. Kształtowanie świadomości wrażliwej na wartość środowiska społeczno-przyrodniczego zależy również od programów nauczania w przedszkolach, szkołach podstawowych, średnich i na uczelniach wyższych oraz od powszechnej edukacji ekologicznej dorosłych. Ponadto jest to priorytetowe zadanie dla wszystkich zdających sobie sprawę z jakości aktualnego środowiska i jego wpływu na życie na naszej Planecie oraz z jego wpływu na życie i zdrowie człowieka w naszej Ojczyźnie, jak i na całym świecie. Jest to zadanie nie tylko dla filozofów, ale dla tych wszystkich, którzy mają wpływ na świadomość społeczną w Polsce i na świecie. ${ }^{5}$

W procesie nauczania - uczenia się warto a nawet należy wykorzystać walory najbliższego środowiska w celu kształtowania odpowiednich postaw dzieci i młodzieży oraz całej społeczności lokalnej.

Pojęcie postawy występuje we wszystkich dziedzinach nauk:

- „Postawa jest względnie trwałą, zgodną organizacją wiedzy i przekonań, uczuć i motywów oraz pewnych wzorców zachowania jednostki związaną z określonym przedmiotem czy klasą przedmiotów." 6

4 L. Nowak, I. ŻEBer-DzikowsKa, Nieformalna edukacja środowiskowa i jej rola w ksztatceniu dorostych. [w:] Ksztalcenie ekologiczne dorostych. Red. D. Cichy. Instytut Badań Edukacyjnych. Warszawa 1998, s. 169-170.

5 J.M. DoŁĘGA, Z filozofii nauk ekologicznych. [w:] Ochrona środowiska społeczno - przyrodniczego w filozofi i teologii. Wydawnict wo Uniwersytetu Kardynała Stefana Wyszyńskiego. Warszawa 2003, s. $35-36$.

- T. MĄDRZYCKI, Psychologiczne prawidlowości ksztaltowania się postaw. PZWS. Warszawa 1970, s. 19. 
- „Postawa człowieka wobec przedmiotu jest to ogół względnie trwałych dyspozycji do oceniania tego przedmiotu i emocjonalnego nań reagowania oraz ewentualnie towarzyszących tym emocjonalno - oceniającym dyspozycjom względnie trwałych przekonań o naturze i własnościach tego przedmiotu."

Postawą środowiskową człowieka nazywamy trwałą organizację informacji o środowisku zgodną z przekonaniami, uczuciami i motywami oraz z uwzględnieniem pewnych wzorców zachowań osób zatroskanych środowiskiem.

W elemencie poznawczym postawy środowiskowej należy uwzględnić zdaniem Dołęgi źródła informacji o środowisku i ich jakość. Autor twierdzi, że wiedzę o środowisku zdobywamy z poznania przednaukowego (potocznego) i naukowego.

W źródłach informacji o środowisku typu potocznego wiele znajduje się przekonań nieuzasadnionych, wynikających z przyzwyczajeń, tradycji, nieścisłych informacji naukowych. Natomiast w źródłach informacji środowiskowych typu naukowego jest wiele krytycyzmu poznawczego, wiedza jest uporządkowana logicznie, uzasadniona, sprawdzalna i komunikatywna. ${ }^{8}$

Ekologiczne postawy dzieci są ważne dla budowy ekorozwoju. Za istotne uznać należy jak najwcześniejsze kształtowanie prawidłowego znaku postawy ponieważ zachowuje ona dużą trwałość w późniejszym życiu jednostki. Dlatego należy zapewnić częsty, bezpośredni kontakt dziecka z przyrodą, gdyż przyczynia się ona do budowania trwałej więzi emocjonalnej z naturą, rozwijania wiedzy i proekologicznego działania. Wskazane jest lepsze, pełniejsze przygotowanie teoretyczne nauczycieli w zakresie kształtowania postaw i wyposażenie w wiedzę merytoryczną, dotyczącą funkcjonowania przyrody oraz znajomość zasad zrównoważonego rozwoju. Kształtowanie i rozwijanie postaw dzieci powinno mieć permanentny charakter, odbywać się we współpracy z rodziną, samorządami, placówkami oświatowymi i kulturalnymi. ${ }^{9}$

Powinno się stale włączać młodzież do aktywnego działania na rzecz ochrony środowiska, poprzez uczestnictwo w akcjach i organizacjach proekologicznych w celu wzbudzenia odpowiedzialności i zaangażowania w rozwiązywaniu problemów przyrodniczych.(Buchcic 2002). ${ }^{10}$

W obecnej szkole można zaobserwować istotną zmianę, przejście w wymaganiach programowych od wyników nauczania do kompetencji ucznia. Dziś zda-

7 Nowak S. [red.] 1973: Teorie postaw. Polskie Wydawnictwo Naukowe. Warszawa. s. 23

8 DoŁęGA J.M., Postawa środowiskowa - próba analizy pojęcia. [w:] Edukacja Biologiczna i Środowiskowa, nr $2-3 / 2004$, s. 32.

9 L. Dомка, Ksztaltowanie postaw ekologicznych u dzieci dziataniem na rzecz ekorozwoju. [w:] Edukacja Biologiczna i Srodowiskowa, nr 2-3/ 2004 s. 60

10 Bucнсіc, Ogólnopolska konferencja naukowa „Edukacja środowiskowa zalożenie i rzeczywistość po reformie szkolnej" [w:] Edukacja Biologiczna i Środowiskowa, nr 2, s. 82. 
niem Bogaja (2000) wymaga się by były to: kompetencje cywilizacyjne (a wśród nich ekologiczne), kompetencje związane $\mathrm{z}$ wychowaniem do wartości, kompetencje związane $z$ etosem pracy, kompetencje związane $z$ etosem nauki, kompetencje związane $z$ komunikacją interpersonalną. ${ }^{11}$

Aby nabyć te kompetencje warto kształtować prawidłowe postawy, poprzez edukacje przede wszystkim w środowisku lokalnym

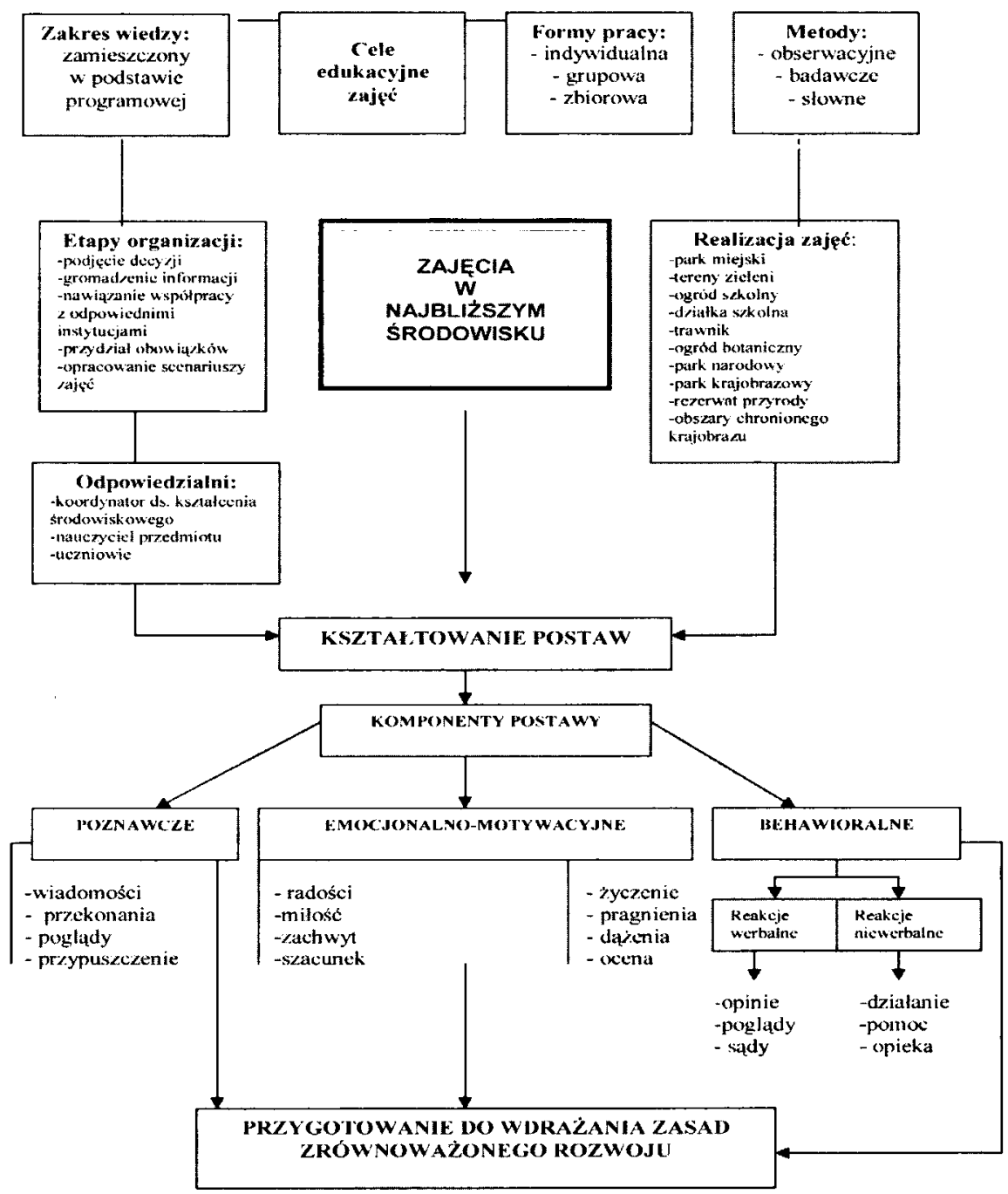

Ryc. 2. Zajęcia w najbliższym środowisku możliwościa kształtowania postaw na rzecz zrównoważonego rozwoju

1 A. BogaJ, Ksztalcenie ogólne. Między tradycją a ponowoczesnością. IBE, Warszawa 2000, s. 78. 
Dlatego warto zmienić sposób przekazywania wiedzy środowiskowej na wszystkich etapach kształcenia uatrakcyjniając proces dydaktyczny, wprowadzając zajęcia, które będą mobilizować do praktycznego poznawania wiedzy i przyczynią się do kształtowania prawidłowych postaw, poglądów i przekonań.

Według Cichy (2005) efektywność procesu nauczania o środowisku lokalnym w dużej mierze zależy od przyjęcia (doboru) odpowiednich strategii, metod i form organizacyjnych nauczania - uczenia się, czyli od umiejętności nauczyciela. ${ }^{12}$

Zdaniem Kozłowskiego $(1998)^{13}$ jeżeli chcemy dokonać zwrotu i realizować założenia zrównoważonego rozwoju, to konieczna jest zmiana światopoglądu i sposobu myślenia. Jest to możliwe poprzez systematyczne uczenie młodego pokolenia myślenia holistycznego, globalnego i ekologicznego. Potrzebny jest globalny zbiorowy wysiłek intelektualny, mający wytyczyć dalsze drogi i sposoby życia na ziemi.

Dlatego należy podjąć odpowiednie działania w każdej sferze działalności ludzkiej: ekonomicznej, prawnej i gospodarczej, aby zmienić światopogląd wszystkich społeczeństw i przygotować przyszłe pokolenia do wdrażania w czyn zasad zrównoważonego działania oraz ukształtowania odpowiedniej kultury ekologicznej.

Zasadniczym celem edukacji środowiskowej we współczesnej szkole jest ksztaltowanie wysokiego poziomu świadomości, czyli odpowiedzialnej postawy czlowieka wobec środowiska. Szkoła powinna odpowiednio przygotować uczniów do podejmowania racjonalnych działań służących ochronie przyrody, poprawie stanu środowiska, dostrzeganiu zagrożeń cywilizacyjnych oraz rozwiązywaniu problemów związanych $\mathrm{z}$ ochroną i degradacją środowiska w najbliższym otoczeniu. Zadaniem szkoły jest umożliwienie wszystkim kształcącym się poznanie podstawowych praw przyrody oraz zasad prawidłowego funkcjonowania w środowisku. ${ }^{14}$

Nauczanie bowiem jest procesem wieloaspektowym i wielostopniowym wiążącym się bezpośrednio $\mathrm{z}$ kształceniem i wychowaniem. ${ }^{15}$

Również edukacja nauczycieli jest (powinna być) przedmiotem szczególnego zainteresowania państw i społeczeństw przejawiających troskę o oświatę i pragnących zapewnić sobie możliwości rozwoju oraz pomyślnego funkcjonowania

12 D. CICHY, Strategie, metody i formy nauczania przyrody. [w:] Ksztalcenie przyrodnicze w szkole podstawowej - teoria i praktyka. Red. D. Cichy Ośrodek Doskonalenia Nauczycieli, Płock 2005, s. 24 .

13 S. Koz£OwSkI, Trwaly zrównoważony rozwój - bariery i dylematy. [w:] Ksztalcenie ekologiczne dorostych. Red. D. Cichy. IBE, Warszawa 1998, s. 34

14 D. CiCHY, Ewaluacja zmian w edukacji środowiskowej wprowadzonych reforma szkolna. [w:] Edukacja środowiskowa. Zalożenia i rzeczywistość po reformie szkolnej. Zeszyty Naukowe nr 31. PAN, Warszawa 2002, s. 19.

15 W. OKoń, Nowy slownik pedagogiczny. PWN, Warszawa 1997, s. 39. 
we współczesnym świecie. To przecież właśnie od nauczycieli - od ich przygotowania i doskonalenia zawodowego oraz nabytych kompetencji - w znacznym stopniu zależy, czy oświata spełni pokładane w niej nadzieje. ${ }^{16}$

Jak podaje Delors (1996) w obliczu rozlicznych wyzwań to edukacja jawi się jako szansa, którą należy bezwzględnie wykorzystać w dążeniu ludzkości do ideałów pokoju, wolności i sprawiedliwości społecznej. Podstawą edukacji przez całe życie są cztery fundamentalne zasady dydaktyczne, tzw. filary edukacji:

- uczyć się, aby wiedzieć,

- uczyć się, aby działać,

- uczyć się, aby żyć wspólnie,

- uczyć się, aby być.

Jak twierdzi dalej autor edukacja powinna przekazywać masowo i skutecznie coraz więcej wiedzy i umiejętności, które ewoluują, adekwatnych do kognitywnej cywilizacji, albowiem są one podstawą koncepcji jutra.

Prawidłowo prowadzona edukacja środowiskowa formalna i nieformalna na rzecz zrównoważonego rozwoju powinna opierać się na wymienionych wcześniej czterech filarach, aby przynieść wymierne efekty w przyszłości, w postaci nawyków i postaw przyjaznych środowisku i przyczynić się do popularyzacji tych treści w szerszych kręgach naszego społeczeństwa. ${ }^{17}$

Ochrona środowiska w wymiarze lokalnym i globalnym staje się tą sferą działalności i aktywności człowieka dla europejskiej konstrukcji - integracji, która powstała w wyniku konieczności wspólnego zarządzania dziedzictwem kulturowym i naturalnym. Znaczenia nabiera ta problematyka pod wpływem wiedzy, wrażliwości społeczeństw na kwestie ekologiczne w warunkach postępującej degradacji środowiska.

To od udziału społeczeństwa polskiego w procesach decyzyjnych odnoszących się do ochrony środowiska zależeć będzie poziom świadomości ekologicznej w wymiarze lokalnym i globalnym. ${ }^{18}$

„Edukacja ekologiczna ma największą szansę powodzenia, jeżeli prowadzi się ją w miejscu, gdzie ludzie mieszkaja, ucza się pracuja i wypoczywaja."

(Polityka edukacji ekologicznej, 1997)

16 T. Lewowicki, Standardy edukacji nauczycielskiej w kontekście reformy oświatowej. [w:] Nauczyciel 2000 - plus. Modernizacja kształcenia nauczycieli przyrody, biologii i ochrony środowiska. Red. D. Cichy IBE, Warszawa 2001, s. 13.

17 Delors 1996: Raport dla UNESCO Międzynarodowej Komisji do spraw Edukacji dla XXI wieku pod przewodnictwem Jacóues’a Delorsa - pt. „Edukacja jest w niej ukryty skarb”. Stowarzyszenie Oświatowców Polskich, Warszawa 1998, s. 215.

18 I. Fudal., Kultura ekologiczna młodzieży. Na przykładzie regionu świętokrzyskiego. Wydawnictwo Akademii Świętokrzyskiej, Kielce 2002, s. 7. 


\section{Literatura}

Buchcic E. 2005: Zielone szkoły - działalność i możliwości podwyższania skuteczności edukacyjnej. Ośrodek Doskonalenia Nauczycieli Płock.

Buchcic 2002: Ogólnopolska konferencja naukowa „Edukacja środowiskowa założenie i rzeczywistość po reformie szkolnej" [w:] Edukacja Biologiczna i Środowiskowa nr 2.

Bogaj A. 2000: Kształcenie ogólne. Między tradycją a ponowoczesnością. IBE, Warszawa.

Cichy D. 2005: Strategie, metody i formy nauczania przyrody. [w:] Kształcenie przyrodnicze w szkole podstawowej - teoria i praktyka. Red. D. Cichy Ośrodek Doskonalenia Nauczycieli Plock.

Cichy D. 2002: Ewaluacja zmian w edukacji środowiskowej wprowadzonych reformą szkolną. [w:] Edukacja środowiskowa. Założenia i rzeczywistość po reformie szkolnej. Zeszyty Naukowe nr 31. PAN, Warszawa.

Cichy D. 1984: Przygotowanie młodzieży do ochrony i ksztaltowania środowiska. LOP, Warszawa.

Delors 1996: Raport dla UNESCO Międzynarodowej Komisji do spraw Edukacji dla XXI wieku pod przewodnictwem Jacỏues’a Delorsa - pt. „Edukacja jest w niej ukryty skarb”. Stowarzyszenie Oświatowców Polskich, Warszawa 1998.

Dołęga J.M. 2004: Postawa środowiskowa - próba analizy pojęcia. [w:] Edukacja Biologiczna i Środowiskowa nr $2-3$.

Dołęga J.M. 2003: Z filozofii nauk ekologicznych. [w:] Ochrona środowiska społeczno - przyrodniczego w filozofii i teologii. Wydawnictwo Uniwersytetu Kardynała Stefana Wyszyńskiego. Warszawa.

Domka L. 2004: Kształtowanie postaw ekologicznych u dzieci działaniem na rzecz ekorozwoju. [w:] Edukacja Biologiczna i Şrodowiskowa nr $2-3$.

Fudali I. 2002: Kultura ekologiczna młodzieży. Na przykładzie regionu świętokrzyskiego. Wydawnictwo Akademii Świętokrzyskiej. Kielce.

Jagodzińska M. 2005: Założenia programowe i charakterystyka procesu edukacyjnego w zakresie kształcenia przyrodniczego. [w:] Kształcenie przyrodnicze w szkole podstawowej - teoria i praktyka. Red. D. Cichy Ośrodek Doskonalenia Nauczycieli Płock.

Kozłowski S. 1998: Trwały zrównoważony rozwój - bariery i dylematy. [w:] Kształcenie ekologiczne dorosłych. Red. D. Cichy. IBE, Warszawa.

Lewowicki T. 2001: Standardy edukacji nauczycielskiej w kontekście reformy oświatowej. [w:] Nauczyciel 2000 - plus. Modernizacja kształcenia nauczycieli przyrody, biologii i ochrony środowiska. Red. D. Cichy IBE, Warszawa.

Mądrzycki T. 1970: Psychologiczne prawidłowości kształtowania się postaw. PZWS. Warszawa.

Nowak L.; Żeber - Dzikowska I. 1998: Nieformalna edukacja środowiskowa i jej rola w kształceniu dorosłych. [w:] Kształcenie ekologiczne dorosłych. Red. D. Cichy. Instytut Badań Edukacyjnych. Warszawa.

Nowak S. [red.] 1973: Teorie postaw. Polskie Wydawnictwo Naukowe. Warszawa.

Okoń W. 1997: Nowy słownik pedagogiczny. PWN, Warszawa. 